\title{
Economy and National Security
}

\author{
Asst. Prof. Dr. Ramazan Kurtoğlu (Istanbul Aydın University, Turkey)
}

\begin{abstract}
After the Great Depression in 1929, “economic security” which was in litterateur after World War II developed and in Cold War period it gained a meaning with neoliberalism which was put into effect with 1978 Washington Consensus. During this period, Soviet Bloc collapsed in early 1990s and a new term emerged in New World Order which is "economic security" equals "national security" or vice versa. Now, these two terms interwined and with a religion - politics philosophy - finance / economics formatted transformation international political economy - mapping and security terms filled.
\end{abstract}

\section{Introduction: The Effect of Economy on Domestic and International Security Perception}

It is known by politics, economics and military that in March 2009, USA did a practice for the Global Finance War with President Obama's permission. Pentagon imposed duty to financial economy experts both from Wall Street and academia during this finance war practice and it is pointed out that the currency wars that started in 2010 will soon turn into a global financial war. It is understood that, the economic national security concept which emerged with the great depression in 1929 and tested in every way with World War II, is becoming more important for today's world. As a matter of fact, Pentagon's economy-finance consultant Rickards's statements are very meaningful: "Upholding U.S. national security interests cannot be done without knowing the dynamics of global capital markets. U.S. dependence on traditional rivalsto finance its debt constrains not only fiscal policy but U.S. national security and military options... The nexus of unrestrained global capital andunstable geopolitics is a beast that has begun to show its claws." At the present time, world economy is at this point.

"Our nation's program of social and economic reform is therefore a part of defense, as basic as armaments themselves.”(Roosevelt 1941:5)

What the president of the US tries to imply with this sentence is that the security of America depends upon the national power, especially the unity of American people. On the other hand, "social and economic security" was the tool of empowering the nation and the President Roosevelt emphasized that the internal and external policies of the US were inseparable and interconnected.

Economical security, as can easily be observed in such departments as social security and especially unemployment, has very important impacts upon external affairs.(Earle 1941: 186-189-193) In this sense, social and economic security is the basis of peace and domestic safety and thus, the programs about this issue are accepted as the first step of national security and national defense. This view first appeared with the Great Depression of 1929 and formed the vision of New Deal program started by President Roosevelt in June 8, 1934. That is to say, national safety is an inseparable part of economic and social security.

President Roosevelt said in his public speech on January 1944 that: "The one supreme objective for the future, which we discussed for each Nation individually, and for all the United Nations, can be summed up in one word: Security. And that means not only physical security which provides safety from attacks by aggressors. It means also economic security, social security, moral security — in a family of Nations.” (Roosevelt 1944)

According to Roosevelt the rights that already existed in American and was brought with the New Deal, the safety of sheltering, education, health and economy all form the domestic security and only this kind of security is the basis of peace. New Deal not only brought economic and social security to the USA, it also was supposed to bring "political security" to the world through the USA as a member of family of nations. Just like New Deal required free (unlimited) expenditure for the great US government's security and progress, international security of post-war also required free expenditure to overcome the chaos created by the war (Schurman 1974:42) . Although we can name this process as imperialism, this world was supposed to become a "liberal world" and was to be formed upon the concept of certain economic order.

Right after the Great Depression, Keynes had proposed a complex, regulated economic New Deal and a reform of public policy that forms a this kind of change all over the world. what he proposed was exactly the system that consists of compromises, controls and balances; which started by Friedman's systemized counterrevolution's state-by-state-refinement. Today, in this respect, Chicago school type of capitalism does not need to have anything in common with the other dangerous ideologies, which means those who believe in the shocking doctrine of neo-liberalism believe that only a great break, disasters, wars or terrorist attacks can create the big, empty plates that they need. 


\section{International Politic Economy-Map and Security}

These theologic-politic-financial "artists" keen on those dangerous opportunities in their hands, start forming a new frame for the world in its most reshapable times/moments when we all can be distorted psychologically and physically disconnected from our roots. The reason why the neo-liberal market economy ideologues assume crises and disasters as appealing is exactly the desire for the holy might for massive creation (Klein 2010: 26) As the issue of fear was forced upon external enemies gradually with neo-liberal globalization, the issue of security began to seem to indicate international dimensions. In other words, the sides of the medallion were economic and national safety. These were the required tools of a political society's security. (Virilio 2005: 170)

According to Robert Pollard, the conception of "economic security" is an economic system idea that is supposed to contribute to the profits of the USA, and that is open and integrated in contrast to a big and systemized army in peace-time. This concept has been powerfully established during the war-time. (Pollard 1985:13)

Actually, the concept of "economic security" is the strategic weapon of liberal capitalism during and postWW2, and as a basic political tool from 1945, is in a close relationship with the security issue. (Pollard 1985:13) In 1943, President Roosevelt was still saying that: “...We must plan for, and help to bring about, an expanded economy which will result in more security" (Roosevelt 1950: 574) Hence, what the Marshall Plan which the US carried out after WW2 was planned on was basically the political purposes (Leffler 1992) Here, it should be emphasized that Marshall Plan was not just a "political intention". It is obvious that this plan is multidimensioned and to separate economic reasons from political reasons prevents us from realizing the fact that economic, political and military reasons are all interconnected. The main idea is that this was a project that is carried out with the ideology of security. In this sense, what forms a basis of security is economic system, in other words capital system.(Neocleous 2012: 72) Marshal Plan and Truman Doctrines are not only a project for "economic security", but also a theological -political intention to re-regulate the global-central capital. This program was of course carried on under the name of national safety. It is quite possible to see this fact in the behind-the-lines of NSC-68. (Etzold, Gaddis 1978:401) To emphasize; the most important document of the US that belongs to the Cold War era is NSC-68. And its basic purpose it still to "shape a world in which US system can survive and grow".

The "New World Order" that has been spoken out since 1990s, and the "Great/Expanded Middle East Project" that has become outspoken especially after $9 / 11$ are nothing but a national security project established with purposes such as "economic security", "political security", "theological security" etc. that seems to "fight against terrorism", frankly "fight with Islamic terrorism". The basic motivation of the project is for Terence Corcoran "untethered neo-liberalism." (Corcoran, 17 Kasim 2006) The economic part of the "government" device, whose theological basis was formed by Messianic Ibn-Meymun (meimonides 1135-1204) and political philosophical basis based on this theological basis was formed by Leo Strauss (1877-1973), has been established by Milton Friedman (- 2006) and his friends in Chicago University Economy and Business Faculty. Friedman advocates that "shock therapy method" is the best model for economy and for this, natural disasters or wars are perfect occasions, just like Meimonides and Strauss. Everything is for the national safety of the state under the control of the "elected".

Hence, according to Yergin, "this new security doctrine of the US is developed to explain America's relationships with the rest of the world." (Yergin 1980: 194) "The historical side of these themes should not be ignored about all the claims about the US's new security assumption.” (Dalby 2002: 7)

Such discourses as the invasion of Afghanistan or Iraq, Wikileaks issue, military attacks against Libya with the mask of "Arabian Spring", civil war in Syria, intentional Turkish plain crash by Syria; the spoken or aliveon-internet war against Iran centered on nuclear power plant, Israel's military attack against Mavi Marmara, the enforcement upon Turkey about "negotiating with PKK" and the rumors about "the change in the maps in the Middle East and North Africa" spoken by secretary of state Rise especially after the invasion of Iraq.

In addition to all, Turkey and its great oil areas on its hinterlands. Boron, thorium, monatomic substance (like gold and platinum) reserves. On the other side, American Evangelist Christian's complete support for Israeli policy because of their belief of Messiah which they were waiting at the first quarter of the 21th century. (Kurtoğlu 2012) Another issue is the politic attractions of Israeli government based on Kabala-Old Testament. The region is like a petrol tank waiting for a spark to blow up.

It is constantly reminded that the borders of the countries, in other words the maps are going to change.

Maps, homogenizes the people on a land through myths about union and artlessness, focuses the political images around the nation state. As an example, a broadcast map which has nothing to do with politics at first sight, bases itself on politic agency. In other words, maps reminds about the collectivism of national area. (Black 1997: 12-17)

Neocleous states that if the governmental and statistic enumeration of population census shows that national population is full of separate subjects, maps first promulgates domestic politic agents, makes these subjects a re- 
united political community and thus builds the national identity. (Neocleous 2003) Second, what maps help is the naturalization of what is possible to happen historically by deleting some important political issues. Every settled order ... tends to produce the naturalization of its own arbitrariness. (Bourdieu 1977: 164)

Now, especially after Iraq's invasion, the USA announced its own map in newspapers, military magazines etc. "by accident" by drawing such maps as "Turkey maps", "Kurdistan maps"; and even Greece announced its own Exclusive Economic Zone in "To Vima" paper, (January, 2013). According to the map, Aegean and Mediterranean Sea have become a Greek lake. If the map were valid, according to it, one seems to transgress the borders of Exclusive Economic Zone and Greek continental shelf if s/he even swims in the sea.

Isn't it obvious that these maps are supposed to contain Turkey in "economic" and "security" manner?

Without maps, the existence of states is under risk. Mapping proposes the expression of "territorial"; to delete a state from a map is to ignore its existence. ... a state without the acknowledgment of the other states is not accepted as a state; it is "out of the map" just like a pirate, mercenary or a terrorist. As a significant political technology of place, maps spontaneously picture the territoriality policy that forms a state and provides it with continuity, but at the same time, masks the ideological and violent nature of the project. By governing the political vision in this way, maps validate the great territoryalization movement thanks to which all the world tends to posses a state. A different form of policy is generally accepted as invalid and out of date. (Neocleous 2012: 282)

The constitution and political/economic regulations in Iraq, as stated by The Economist "the national yard sale" (Economist, 27 September 2003), which is supposed to be performed in the region, especially in Iraq after the invasion, indicates that "military neo-liberalism" and "economic neo-liberalism" match and what is actually being done is nothing but capturing. (Robert 2005: 11, 43, 75)

Winston Churchill, one of the politicians of England and the inventor of Middle East and North Africa at the beginning of the $20^{\text {th }}$ century, says in 1936, in Palestine Royal Commission while talking about the probable Jewish state meant to be established in Palestine: "You all saw the sets on those hills that used to be cultivated but have become deserts with the Arabian government. Those areas should be cultivated and planted for the profit of all the world, Arabians are never going to cultivate, this is unfair." (Gilbert 1978: 176-177) Chaim Weizmann, the chair of World Zionist Organization said for the same issue that: "Palestine rebellion is nothing but a stand of a desert against civilization." ( Gregory 2004: 81-82) Today we call it "Clash of Civilizations" in the Divine Empire or in a more secular discourse "New World Order" project. ( Huntington 2002)

We witness the argument that proposes that "the reason for the destruction of the difference between war and peace is the impact of the war machine upon the daily culture" and "that a long lasting epistemic shift that blurs the old separation of war and peace has occurred" (Debrix 2008:97)

\section{What is Political about "Economic Security" and "Military Security"?}

Carl Schmitt says that "what is political is the most violent and excessive adversity." , and the closer this concrete adversity gets to its peak, which is the separation of friend-enemy, the more political it gets. The nature of friendship lies behind a couple of common values that separates friend from "the other and alien". (Scmitt 1996: 29) When we take a look at the relations between Turkey-US and Turkey-Israel, especially from the $1^{\text {st }}$ Gulf War to today, we see that it exhibits an improvement that proves what Carl Schmitt says. According to Schmitt, the entity of the adversity of friend-enemy is the political one. In this process, what decides this particular adversity is the dominant one." (Schmitt 1985: 5)

At this point, the review of Serdar Turgut is quite significant: "there is this global profound power that prevents governments from breaking the rules that themselves establish to regulate the global world, makes the conflicts fixed up in a safe way and that looks out for the economic benefits of capitalist world system. It is obvious that this profound power is constantly messing with Turkey recently. .. What I see personally is that Turkey is now the target of this profound power. This is also quite normal, expected situation as the keepers of this global system have been dealing with the new geo-strategy that has occurred upon the fall of the Ottoman Empire since the middle of the $20^{\mathrm{th}}$ century. And the question of what Turkey is going to do is the most important issue in these global system-creators. (Turgut, 10 January 2013)

There is more than "economic privatization" that neo-liberalism is dealing with. First, the security fetish has been proposed. Then, "the privatization of security" has come into play under the name of security. In the international market, the income of global security got up to $\$ 56$ billion in 1990, and got more than $\$ 200$ billion in 2000. Now, the stock certificates of security companies are traded.

The conceptual consistency between economic security and the construction of new world order meant that "economic security" can be shown right by putting the economic, thus "humane" needs on an upper place than military needs on neo-liberal base. The global central capital's production process of the New World Order supported by media and Hollywood seemed more humane in this way. This outlook helped taking liberal left into the sub-constructors of neo-liberalism. Of course it also brought such ideas as "individual liberty", "social 
equality" etc. into question by emptying them. As a result it came to the desire for "individual" and "social" security. (Neocleous 2012: 75)

Neo-liberal global power launched the connection between economic and national security as a dependence on capital security. This meant a dependence on national security. For the past 40 years, the US aimed to re-shape the international society by governing the global order according to a security doctrine that has loyalty on capital stock rather than being "reactive" or "against" under the cover of national security. (Neocleous 2012: 76) Rather, economic security became very important for the theory and practice of both social and national security by connecting local with international, domestic with foreign issues, and became the cornerstone of the security project. (Neocleous 2012: 77)

We should also emphasize that the US is the Economic Security Committee that has been on execution since June 1934 with the 6557 act.

It is important to state that today national security operations and/or strategies and (international) politic economies are considered together, because it is quite apparent that there is an obvious connection between national security and economy issues. For these reasons, the main actors of the global politics could never separate security from politic economy. (Neocleous 2012: 52) Already in the 1940s, many important academicians emphasized the supplementary relationship between economy and security. (Hirschman 1945)

Recently, it has been observed that this economic security issue is dealt with more religious discourses, Messiah, Armageddon, Gog and Magog, Apocalypse War, Third World War etc. In this sense, "now, in both East and West religion is more of a political issue... It is getting more and more secular while getting more politic and becoming the main element of every kind of policy.” (Kahraman, 20 June 2010)

\section{Perception of Economic - Political Security in a Theological Format in Turkey and its Hinterland}

The fact that my evaluations and foreseeing In my book named Evangelism are getting true since 2006, scares me in the matter of not only my own country Turkey, but also Turkish people, Islam world and humanity.

"Although in the post-modern world religion seems as poor as a scrappy cottage, it should not be forgotten that whatever is not under the roof of academia is presented to them in the sanctuaries. Prophecy, which is hope, which is miracle... human beings find themselves in sanctuaries. In poverty." (Cündioğlu 2012: 92)

Messiah/Mahdi phenomena can take Turkish/Islam geography into exactly a nuclear, biological and chemical war. For the first time in history, with various belief and estimations; the "messiah that the Jews coming from King David wait for", "Jesus Messiah that especially Evangelist Christians wait for", "Mahdi (Çağlayan 2012), who is the lost $12^{\text {th }}$ imam that Shiite Islamic Muslims headed by Iran wait for" and Mahdi, for whom some of the Sunni Muslim sects or societies wait, and the speculative political attractions and the "strong belief" for the coming of Jesus at the first quarter of the $21^{\text {st }}$ century can all overlap in a surprising level. We do not judge people for what they believe. But what is surprising is that these believers with different beliefs have things in common with one another about the expectation about Messiah. Another desperate and concerning part of this issue is getting more and more serious. The expectation of Messiah/Mahdi that I mentioned above is becoming such a social hysteria that all of the sides "call God for Apocalypse" for the Messiah/Mahdi to come.

The Kabalist celebrity Madonna who is famous for drinking Kabala water knows no bounds about the "cleansing from sins theology" on which the expectation of Jewish Messiah is based. She masturbated in front of thousands and especially her 12-year-old son, during one of her concerts. (Türk, 14 November 2012) The Kabalist celebrity Madonna showed her breasts to the audience in her concert in Istanbul in September, 2012, and in another, her hips. On the other hand, Evangelists, Zionist Israelis and the top directors of Iran, keep on with the "cold war" that announces a probable nuclear, biological or chemical war for the Messiah/Mahdi. Especially in the Western Israel, around the Israel supporters, a doomsday scenario has been composed. According to this, Ahmedinejad who is a member of a secret sect that believes that beyond the classical Shiite Mahdi expectation, Mahdi's return could be fastened with a big war, is planning to attack Israel with the weapons that he would get from the nuclear programs that he keeps and fasten the return of Mahdi." (Çağlayan 2012: 310-311) With a similar plan, an Armageddon War is being foreseen, which is planned to quicken the return of Jewish Messiah from King David's roots and Evangelists' Jesus Messiah. (Hallsell 2003) Similarly, some sects and societies from the Sunni Islamic district publish books, essays and make TV/radio programs with the same view. Besides, Directorate of Religious Affairs of Turkey has placed a fetwa that supports them. According to the fetwa, apocalypse has "small signs" and "big signs". The big signs include: "It has been informed in this hadith that without the ten signs, the doomsday will not come. Coming of Anti-Christ (deccal), return of Jesus Christ, coming of Gog and Magog, coming of Dabbetül Arz,...”(Hürriyet, 16 December 2012) It is quite enough to mention that such a fetwa displays that the council of Directorate of Religious Affairs is full of simple minded and uneducated people, because Qoran says nothing about the return of Jesus Christ. Those sentences that they call "hadith" is nothing but rubbish that is only spoken around. In this matter such a question 
can arouse in minds: "Is the issue of Messiah/Mahdi a phenomena that is achieved through the same center, with a simple saying a phenomena abused for a world war?" we leave it without critique because of the respect for our readers. However, for the Religious Studies Professor Bayraktar Bayrakl,, "All these beliefs (Deccal will come, Jesus will return etc) are pure superstitions." (Bayrakl1, 21 December 2012)

Those legitimate global elites that control the central capital and form the supernational clan canalize with the reward mechanism in fields like spiritual world, business world, politics, arts (especially cinema and music), culture and science through plenty of non-governmental organizations and groups. The two most important ones of these is the Nobel and Oscar awards. It may sound weird but two favorite names of weapon companies, David Trimbel and John Hume were nominated for Nobel Peace Prize in 1999.

English Chatham House, dozens of "international" institutions from Tavistock Enstitute to US Council of Foreign Relations are controlled and canalized from one center. The aim is to establish an esoteric globe state that they named as "Divine Empire" under the Secular definition of New World Order. In fact, it has nothing to do with any of those divinities and religion, they only "appeal to religion" to persuade masses and armies. In conclusion, what they want to achieve is:

A To prove the complete sovereignty of global central capital all around the globe,

A To leave the control of the earth to a bunch of elite under any circumstances,

A To turn celestial religions into one only syntretic religion, thus for this, to melt Islam in the pot of "Abrahamic Religions" by leaving it without Mohammad,

A To impose an elitist, fascist/company socialism model to humanity under the name of "neo-liberal democracy"

The clan of elites can apply to every single way to achieve their aims. This clan, which is called "the Sect of New World Order" (Alatlı 2005) by Alev Alatl1, are preparing for the Third World War by generating regional fixation wars and "global shocks from tiny probabilities". (Kurtoğlu 2012:1) Hence, 9/11 and after, 2008 financial crisis and the process after it, Wikileaks issue, Arabian Spring and worthless attacks against the Islamic prophet Mohammad and Qoran are only some of the operations of the same center.

Mine G. Kirkkanat, in her assay named "From Prophecy to Apocalypse" refers to the Evangelist Messiahs and prophecies about the Armageddon War. (Kırıkkanat, 1 July 2012)

Kurkkanat states in the same essay on September 27, 2002, that she touched upon the same issue with the title "Prophecy of Daniel" and emphasizes that "Daniel Prophecies" have focused on Turkey again.

"the Rumor is quite large and diverse, but Daniel starts the apocalypse that he divides into seven steps from Turkey's basin of Firat River and finishes with the world war that is supposed to take place in Great Palestine (not Today's Palestine), and in the Armageddon region that is a great part of the Middle East. As I understood from Daniel's poetic mysteries, out of seven cavaliers of the great crowd, the sixth one is going to finish. First, the waters of Firat is going to dry, Anatolian lands are going to burn under the burning sun. Then, God knows where(!) an earthquake will take place. The conditions will force the kings (or armies) in the East to come down to Armageddon. And right there, in the Middle East, a war will break out with the Western armies. The reviews about these prophecies also not only show Turkey as the starter of the doomsday, but also they foresee that its borders will get smaller, a disaster will sweep away the Turkish nation, the end of Turkish government on the region and the beginning of armageddon war!

There is for gravestones that are assumed to be Daniel's: Uzbekistan, Iran, Kirkuk and Turkey (Tarsus).

Strangely, in the year 2012, when Turkey sent masses of soldiers to the border of Syria, Daniel prophecies again focused on Turkey in the websites. And there is a new prophecy, says Kirkkanat, no comment... here is the prophecy:

"23/after the sinners conflagrate and their impacts fade out, an insolent and trickster emperor will come out. 24/ his power will grow but it will be someone else's; will give incredible harm, will succeed in his attempts, will cut off the competents and saints. 25/ the abundance and his gains with his tricks will surround his heart with hubris, will ruin many peaceful lives and will fight with the leaders of leaders but will defeat himself without anyone's interventions."

Tom Schelling is an economist with a Nobel prize. His profession and under cover is terrorism, to prepare "counter-attack/anti-terror" scenarios by foreseeing the worst. As a result of the analysis that he come up from the intelligence reports coming from CIA, MOSSAD, NSA and many others, he came up with the idea that now the enemy - especially the "Islamic terrorists" have started considering about using nuclear weapons and from him, every day can be the last day of all humanity. Schelling, the 90-year -old game theory economist, is "renewing" his kitchen in his house in Bethesda Maryland, around Washington DC by spending thousands of dollars. Actually this is what he wants others to know. What he actually does is a nuclear refuge in case of a probable nuclear attack against the US. (Turgut, 25 November 2012) How about this? Hollywood came up with these movies in regular periods: Arlington Road, Under Siege and Swordfish... then here comes the 9/11 attacks in accordance with the scenarios of the movies. Just like in three of these movies, all the criminals were "Muslim 
Arabian terrorists". Remember, now those preparing for a "nuclear attack" in such TV series as "24" are all "Muslim Turkish terrorists". What do you think? Can Turkey be the target this time?

\section{Report of "Global Tendencies" Published by NIC}

The National Intelligence Council (NIC), which is the top intelligence organization of the USA, published the last "search of global tendencies" made every four years on December 10, 2012. The report proposes the "predictions" and dynamics of 2030. the most important "prediction" about Turkey is on "the impact of an independent Kurdistan on Turkey's powers". The report states that Turkey's territorial integrity is in danger and in 18 years, until 2030, a division of land is expected. Matthew Burrows, authority of NIC, states that Turkey will be the first country to be effected from what is going on in Syria by reminding that the war in Syria was the outcome of the expansion.

One of the cases in the "Global Tendencies 2030: Alternative Worlds" report, depicted as "game transformer", are arranged as:

- Global economy open to crisis

- Fondness of governability

- Increasing working potential, both within and international

- Tendency of increase in local inconsistencies

- Effects of the new technology

- Role of the US

While the US is becoming an exporter of gas and petrol, the increase in such important issues as expenses of education to prevent a decrease of quality, and health. According to the report, $60 \%$ of the world population is going to be living in the city centers in 2030 for the first time since 2006 . Another issue is that Asia is going to be the center of world economy. According to this report, which talks about the four great tendencies towards 2030:

- The middle class is to increase in the world population. The world population which is today 7.1 billion, will be 8.3 billion in 2030 .

- Separation of powers, China is to outreach the USA, but will look for a local partner.

- The population will get older especially in Europe, Russia, China and Japan; Pakistan, Afghanistan and Africa will be out of this process.

- Food and water will be harder to reach.

"In short, the NK report has a great significance to read the perspectives of the US deciders about Turkey for the coming period." ( Ergin, 21 December 2012)

Let's get back to the lines of the "Global Tendencies 2030" report concerning Turkey and the region.

Condoleezza Rice, the National Security Consultant and Foreign Affairs Minister during the term of Son Bush said that in 2004, the borders of 22 countries are supposed to change in the Middle East. Rice implied that Turkey can disintegrate referring to Egypt, Iran, Turkey Syria short before the publication of the report. More or less in the same period, American Ambassador of Ankara, Morton Isaac Abromowitz also said that 2014 is a critic year for Turkey. (Abromowitz, 20 September 2012)

The former editor of National Interest magazine and US Marine Forces Academia lecturer Nikolas K. Guasdev stated in February 2012 that "Syria issue" is an understanding that is called "Syria norm", which limits the rights of the state to have counter force for the rebels, and he said that the understanding of government in the international system whose sovereignty rights have been determined with the Montevido Treaty is no more valid. According to the American academic, in a short period, "Syria norm" will make the counter-attacks against PKK in Turkey, FARC in Columbia, Marxist and Islamic rebellions in Philippines more questionable, and as a result, the countries in question will have more restrictions in their sovereignty on certain regions of their own land.

It is obvious that the decision of formation of Turkey and its hinterland on an ethnic and religious sect base since the mid-1970s. and that the project was initiated by American National Security Consultant Henry Kissinger, and that the project carried on successfully in Lebanon.

In June 1978, headed by Bernard Lewis and sponsored by Kissinger, a meeting was held in Princeton University to which well-known experts in concern with Orientals and modern Arabian countries attended. One of the calculations of the meeting was the redrawing of the borders according to the religious sects and beliefs of the $19^{\text {th }}$ century.

Similar perspectives were included in Kivunim (Directions) magazine which was made the media organ of World Zionist Sect by Oded Yinon more clearly. (Yinon, February 1982: 14) 
In his "1980s Strategies for Israel" essay Yinon states that the ethnic and sect structure of all Middle East including Iran and Turkey poses great occasions for Israel. According to him, Iraq should be divided into three, Syria to six different states.

Jewish General Wesley K. Clark who commanded NATO's European Unions (1997-2000) and who carried out the operation that was planned against the David Koresh Sect in Wako Mountain, Texas; which was bloody, had ended up with the death of many women and children; explains the ideas parallel with the ideas above with the name "fight with terrorism" in his book" Winning the Modern Wars-Iraq, Terrorism and American Empire" written after the invasion of Iraq in more detail.

It is clear that the map of the region which includes Turkey, as well, is apt to change. This is not a prophecy, it has already started. Actually the US announced that the maps are to be redrawn in our own region short time ago. Also, Condoleezza Rice, Foreign Affairs Minister of Bush has already emphasized this fact clearly. (Turgut, 27 November 2012)

\section{Geography- Economy-"Fate"}

Robert D. Kaplan is a familiar name for Turkey. The name of his last book is "the Revenge of Geography: What the Map Tells Us about Coming Conflicts and the Battle against Fate"

Kaplan says in his 19 paged essay "On the Coming Anarchy on Our Planet", he asks the question "why should Turkey have built the dams in the Southeast Anatolia Project, which would go out of its possession?" in 1994. (Kaplan, Şubat 1994) This essay was one of the 80 essays written in the Balkans which was the hot spot of Europe, and it was included in his book "Balkan Ghosts", one of the most important 14 books that he wrote. As Serdar Turgut states, "his manner is surprisingly like John Reed, which was the author of the books Ten Days and Insurgent Mexico. He observes and reads the countries that he visits. This kinds of people release the strategic facts that even the secret services cannot."

Kaplan works as the head geo-politic analyst in Straford referred to as open CIA.

Today, to understand the politics that Israel and USA carry on in the Middle East, one should closely examine the prophecies that Kabala+Old and New Testaments say, and study Batıni/esoteric interpretations that especially the Evangelist Christians have out of holy texts. About this issue what Serdar Turgut has to say is that "... Whereas what motivates Israel and their supporters in America is the beliefs and ideas which would sound totally irrational and non-sense. We can explain neither Israel nor America without understanding this situation."

To be able to do this, we should be aware of the secret histories of these countries and esoteric sciences. I, out of curiosity, examined the secret beliefs and superstitions that motivate Israel. So, none of their crime against humanity seems surprising to me. I was expecting these, because they believe that they were fulfilling a great mission that they were assigned by divine beings. Their supporters in Israel and America -Evangelists RKbelieve that fighting is their destiny, moreover these wars were written in their religious sources and they were ordered to do so." (Turgut, 22 November 2012)

According to Serdar Turgut, the people under the control of Israel, which believes that their country is preparing for a war that will bring the end of the world according to the "Israel war calendar", are planning every aspect of their daily life according to the Sabbath calendar. This calendar indicates that Israel's new war is supposed to blow up nowadays. And now guess what! There are many that believe this war is going to be with Turkey. There are also those in Israel and America who believe that this is written in the religious sources about the end of the world. According to this story which is not only told but also believed in, this war with Turkey will not directly lead the world to the final destination, but it will lead it to armageddon, the war that is supposed to directly end up the world. These people believe that the process towards Armageddon must be triggered with some provocations and attacks, because Armageddon is going to take place on the day that Jesus Messiah is supposed to come down to earth. With this belief, the Evangelist Christian communities in the US plump for Israel... Armageddon is going to take place in the Megido Hill on the north of Israel. On the day of Armageddon, it is supposed that some enemy countries will come up to Megido and establish coalitions in this region. This coalition, which would definitely include Turkey and Iran, will go to war with Israel, which would be bloody and include nuclear weapons. (Turgut, 22 November 2012)

On the other hand, the Judeo-Christian perceptions about Turks being a sign of doomsday in the West date back to the ancient times. "thanks to the massive communication devices a famous Turkish enemy outlook was formed using the religion and government war propagandas." (Coşan 2012: 11) For example, as a result of Martin Luther's naming Papacy and Turks as Deccal; this idea was obtained by both Protestantism and Catholic Christianity. (Coşan 2012:161)

During the construction of the New World Order, the last country to be conquered is EDOM. According to Kabala, the holy texts that underlies the Jewish mysticism, "Edom" was the ancient name of Anatolia that covers most of the Turkish land. (Nirun 2006: 9-208) Anatolia is within the promised land. After all, Edom was the name of the country to be conquered with the last victory. We need to say that what we live through now and the 
Middle East paradox is way beyond the surface on which such covers as Saddam, petrol, water and Iran's nuclear power are held as any human being can realize. It is not wrong to think that the world is seriously going towards the Armageddon, which is the last war in the Middle East based on the Apocalyps symbolism. Now we should think more universal and understand why and how one serves the other. We are running out of time and our only solution is Ataturk's worldview and regional policy. God knows, maybe he foresaw all these in Seljuk in 1933 and emphasized today." (Nirun 2006: 208)

The hegemonic aims called New World Order are not only supported by the divine/holy texts. The military expenses of the US -so do Israel- in total is same with the 15 forces' budgets in total that comes after America, and more than twice as much as the EU and NATO expenses in total, and close to Russia's GSMH. Of course the unilateralist policy of the US is not a policy that is started by son George W. Bush, but it has earlier roots (Clinton, as well). (Huntington, Nisan 1999) But this unilateralist policy with Evangelist and neo-con supported Bush caused US' closest supporters to blaze. (Nye, National Interest 2001/2) However, the powerful, rich and strong elites that risk everything for the world hegemony and God Empire both in Israel and in America are still around and "the Islamic terrorists" are remarked with such an observation: "... but if some of them are determined enough to attack you for the sake of their creator, they are probable to succeed. In short, if you want a world hegemony, you should be ready to pay for it." (Isenberg, 30 October 2000)

An example to indicate that they can do very dangerous things to attract the American people and army and "to make global shocks on weak probabilities" (Kurtoğlu 2012) as an indication of the seriousness of the danger that Turkey and Islamic world face: author Christopher Bollyn tracked 9/11 issue for years. In conclusion he published his "Solving 9/11 the Deception that Changed the World". According to the book, Bollyn traced the people whose names were involved in the attacks just like an intelligence agent. He followed the indications to the last and searched if there was a control plan in the 9/11 attacks. What he reached was that behind these attacks there were Jewish/Evangelist Zionists and this business could go even to the corridors of some institutions of the shadow government of the US.

"End of Times", "Armageddon War" are basically American-centered. The belief that Israel was in a holy war and the Armageddon War will show up eventually started within small communities in America, however, it spread throughout the country thanks to some films and book series like "Left Behind", and ultimately the idea reached to a great deal of supporter masses. The novels gathered under the title "End of Times" are written on the basis of the Kabala, Old and New Testament texts, although they seem to be products of science fiction. Americans read these type of novels with a great interest and emotions. This type of literature is called "Apocalyptic Literature" and the most famous author of this genre is Tim La Haye. the civil staff and supporters in the security and intelligence communities in Washington of this idea, especially that of Pentagon are highly abundant. (Turgut, 23 November 2012) For most of these people, Israel is as important as the US and most of them have Israel passport. The power that Israel has to be this reckless is coming from these supports. These powers are determined to get into a holy war with Israel. And they are ready to get rid of any person or power that prevents them from getting into action for their goal. (Turgut, 23 November 2012)

It should not be an overestimation that these irrational stories actually determine the policies of the US Israel. "using nuclear weapons, killing women and kids, sacrificing thousands of people for their non-sense goals is not for rational people; but as these people are the blind captives of the stories told in those holy texts, many people cannot understand the attitudes of America and Israel. (Turgut, 22 November 2012)

The Israeli government has such a faith in this process that the signs of these religious sources can be seen in everything they do. A short time ago Israel secret service sent a computer virus to sabotage Iran's nuclear system. Even in the program texts of these viruses named STUXNET there are references to the part that is about the victory of Jews against the Persians in Torah. These insane people believe that a third Solomon Temple should be built before the return of Messiah. They believe that the Third Solomon Temple is on the sky and that the new temple should be built exactly under the shadow of that temple on the sky. Now, on the spot that this shadow is believed to be, there are two Islam temples, Al-aqsa Mosque and the Dome of the Rock. They say that for the construction of this third temple, those two Islam temples have to be collapsed. (Turgut, 22 November 2012) All these may sound weird, but it is good to remember Italian thinker Umberto Eco's words: "Do not debate over a belief's wrongness and rightness, think about what they could/can challenge for what they believe." It is obvious that "great catastrophes are expected for the world and all the humanity." (Eygi, 27 April 2006) According to the "Alternative Worlds" report that is prepared for the 2030 global tendencies by National Intelligence CouncilNIC, which includes all the intelligence agencies in America, the Islamic parties will be more ECONOMIC, in other words, it will turn into a neo-liberal "market Islam". Again, the report emphasizes that the political Islam is taking over the control in the Sunni Islamic world by showing Turkey, Tunis and Egypt as examples.

Mehmet Şevket Eygi says: "I do not know where, when or how but a great bloody war named Armageddon will break out. I can hear the bells. The bells of the war are not like those of humans. Those who can hear can, and who cannot, cannot... Iran is a big deal. They cannot deal with it by themselves. The best way is to crash them with another Islamic country. Thus, they could do two things at the same time. Iran can disintegrate and become slave, so can those countries with American supports... those Arabian originated and Sefarad Jews in 
Israel are the second-class Jews in America. There is a black panthers movement that fights against racism and Zionism in Israel... on the other hand, there are crypto-Jews in every Islamic country. These people can go to the mosques, pray, fast and go on pilgrimage. They seem to be more or less Muslim from outside, but they still have the Jewish identity in themselves. Bi-identity, bi-religion is acceptable for their religion... just like this, they want to assign seemingly Muslim, actually Jewish governors for the US/Israel and Islamic countries. And they call all these issues the war of good and evil. (Eygi, 27 April 2006)

The 114-paged study "Study on a possible Israeli strike on Iran's nuclear development facilities" carried on by Center for Strategic and International Studies-CSIS, centered in Washington DC indicates that right after such an attack, thousands of people will die, and the radiation clouds will endanger the lives of hundreds of thousands of people in countries such as Bahrain, Qatar, the united Arab Emirates, Turkey, Azerbaijan, Georgia, Armenia and many others. Thus, US president Obama and a group around him are debating over the need for a cyber attack against Iran at first. According to the facts that we obtained from open sources, they have been working on this issue since 2010. And the US passed a document named national cyber policy for the first time in its history and a cyber commander was appointed to National Security Council.

In these "cyber war" plans, it is very significant to collapse the target country's economy. It is frequently mentioned that this system based on the collapse of economic substructure would attack the neighboring countries of Iran and subsequently cause a global financial crisis.

It is known that a successful attack against Iran's nuclear facilities was carried on with a computer virus named STUXNET in 2010-2011 and it could stop the work in the facilities. What is strange is that it is predicted that Israel was supported not only by the US, but also China with this attack. Apparently in a short time, Israel and the US will break out a cyber war that will effect every single country in the territory especially Iran.

The prophecies about the 12.12.12 of Mayans have passed. There was no apocalypse, but it should not be an overestimation that in the coming 30 years, we will have a period in which moral values, religious issues will effect humanity more and at the same time the holy texts will be abused with esoteric/Batıni interpretations.

\section{An Inefficient Economy Theory: Neo-liberalism}

The economic model of neoliberalism which was started officially with Washington Consensus in 1978, collapsed with the financial crisis of 2008. "the financial and debt crisis revealed that economy discipline was in a crisis, as well. The models that the main currency economy has improved are no more efficient to reflect reality and make true analysis. What kind of a solution can be found for financial and debt crisis? Will the inflation disvalue our money? We had never needed the comments and analysis of the economy experts as much as now before. But the thesis that both the main currency economists and Marxist economists have reached have started to be criticized densely. Now nobody believes that the free market can heal itself anymore." (Ulrich 15 September-November 2012)

Prof Thomas Straubhaar, who is the director of the research center named World Economy Institute in Hamburg in Germany says that: "Even the basic rules of the economy discipline must be questioned. Economy discipline does not have such unquestionably valid rules that can be foreseen and followed like in physics. Thus, we should not attempt to come up with standard recipes for extremely complicated issues." But from the middle of 1970s IMF and WB and from the middle of 1990 WTO imposed the standard recipe for the countries all over the world. Fund manager and author Prof. Max Otte is one of the true-predictor of the global financial crisis in 2006. But on the other hand he admits that neither the main currency economy models nor academic economy knowledge is enough for the solution of the crisis. Today's economy can only provoke and increase the crisis. Otte is the first of those who claim that economy is inefficient to explain the current crisis scenarios of the modern economy. While advocating that behavior economy as a new branch of science does not have the deserved interest, Otte continues: "the impact of prejudice and emotions upon behaviors is getting more attention. Thus, the number of those who demand economy to combine with religion, sociology, philosophy, history and even biology is increasing." Because it should not be forgotten that the issue is the human being and its social progress. The importance of imbalance and power distribution and the importance of the distorted knowledge should be considered. There is not only one market that the main currency economists applause and tried to be continued for 20-40 years, there are, instead, many markets.

What has gone bankrupt with the financial crisis of 2008 is not only neo-liberalism but also the "prophecies" that formed the theological basis of neo-liberalism. Here are some of them: a- a one world state-government will be established. (Vahiy 13:7; Daniel 7:23) B- a one world economy management will be established. (Vahiy 13: 16-17), c- a one world-syntretic religion, belief government will be instituted. (Vahiy 13: 3,4,8) When we take a look at the process from the past to the present, Holy Scripture is the basic element of Judeo-Christian consciousness, a basis that cannot be underestimated. Again, from the past to the present, the military and economic gains of the West have always been bloody. So, while searching the policies of TOMORROW of the Judeo-Christian Western world, we should not forget that the things having happened from the past have been "suspended and blessed with the obedience of prophets" as it is not a prophecy to say that tomorrow will be the 
same. We have to see the danger before it happens. The 9/11 "operation", invasion of Afghanistan and Iraq in 2003, financial crisis of 2008, Wikileaks and Arab spring... All these are the operations based on "the global shocks on weak probabilities" (Kurtoğlu 2012) of New World Order project. In this case, the code name of Syria crisis is "Leviathan". (Turgut, 23 July 2012)

Leviathan is an expression with Kabalan roots that is a Jewish mysticism, and a reference to "God Empire" that owns exact power and might. Thomas Hobbes's book published in 1651 named Leviathan, is the code name of the operation against the territory that includes Turkey and its hinterland today.

Turkey's land governs a great area that has boron, thorium that is the new generation nuclear energy fuel, gold and platinum that are the monatomic elements and 453 billion cubic meter of natural gas reserves that are found in East Mediterranean Sea and Cyprus. "today there is a great probability that this struggle carried on secretly for a long time would turn out to be a great war.’(Turgut, 23 July 2012)

The biggest world powers are carrying on military exercises in the Eastern Mediterranean Sea. There is an unusual increase in the number of the Russian war ships passing from Turkish channels arriving at Mediterranean Sea.

"The Israeli submarines loaded with nuclear weapons are running around in the Eastern Mediterranean. It also turned the Greek Islands into military bases. These Greek Islands loaded with weapons have become Israeli airplane carriers. We also need to remember that 100 Israeli airplanes are used in the military exercises carried out in Crete Island and also 2-300 missiles are used, as well.” (Turgut, 23 July 2012) Besides, it is not a hidden information that China also shows its navy East Mediterranean as target.

As academician and columnist Serdar Turgut writes: "some people pushed the button somewhere again and the massacres started in Gaza. It is for sure that the crisis of Mavi Marmara and break of Israel-Turkey relationships are the tools that these "some people that pushes the button" use to create an inconsistency in the region. Getting Turkey into a war is required by the destabilization policies of these power who seeks for the inconsistency. We should consider the fall of our planes and not only exterior, but also interior war calls after the incident in this respect. One of the best ways to fasten the inconsistency is to make a disinformation operation. This kind of operations including cyber attacks war is already being practiced against Lebanon, Iran and Syria. It is quite obvious that they aim at Turkey, as well."

\section{Conclusion}

Turkey now has to practice those short-medium-long term precautions needed more in two occasions, while taking increasing deterrence of Turkish army, which Ozdag calls HARD POWER: (Özdağ 2012: 1) first, as Sait Y1lmaz explains in "Smart Power", "Turkish Armed Forces should establish a cyber war command according to the examples of those in the West for cyber war and information war... the danger in social media should be seen; the national versions of microblogs, facebook and twitter accounts should be promoted and used. Our intelligence system should be encouraged to use social media more." (Y1lmaz 2002: 439) Second thing that should be done is to take lesson from 1838-1914 period of the Ottoman Turkey. As we know in this period, the liberal economy formed of judicial-economic-politic regulations in 1838-1839-1854-1856-1881-1908, has quickened the fall of Muslim Turkish traditional trades lacking an equal competition, and increased the activity of the foreign capital and non-Muslim elements in economic area." (Toprak 2012: 557)

When we compare Republic of Turkey's 1950-80 period in which it practices "Complex Economy-Import Substitution" with the period from January 24, 1980, on which it started to practice neo-liberal policies to today, we unfortunately see that the latter period is more pessimistic than the former and reminds about the 1838-1914 period of Ottoman Turkey.

The progress after the 2008 global financial crisis shows that, the financial sector of economy at the first place especially the strategic sectors' being "national economy" formats is quite important. It is obvious that in the coming period more protective policies will become prominent in the international economy field, which means national economy will never lose its importance in any period.

Turkey should not estimate its national security separate from "economic security" and should take necessary precautions about the "maps" issues without losing time. In other words, Turkey should also be "strengthened with independence and economic independence" as Gazi Paşa says.

The most apparent quality that postmodernism and neo-liberal globalization brought to the present humanity in the last 40 years is "wastage" for Zygmunt Bauman. Just like the weeds being the waste of the garden, "unqualified streets are the waste of city planning, contrasting ideas are against ideological entity, rebelling ideas are waste for orthodoxy and foreignness is the waste of nation state construction" (Bauman 1991: 15)

The most important issue here is that many "common areas" of "nation state" and "national society", time, recovery and solution are all wasted with unnecessary arguments and separations. And Turkey cannot continue this and this kind of luxury any more. 


\section{References}

- Robert, "Afflicted Powers: Capital and Spectacle in a New Age of War", Verso, London, 2005.

- Aktaran, Martin Gilbert, Exile and Return: The Emergence of Jewish Statehood", Weidenfeld and Nicolson, London, 1978.

- Albert Hirschman, "National Power and Structure of Foreign Trade", University of California Press, Berkeley, CA, 1945.

- Alev Alatl1, "Kabus", Everest Yayınları, 16. Bask1, İstanbul, Mayıs 2005.

- Ata Nirun, "Panaya Kapulu-Meryem Ana Evinin Sırrı", Destek Yayınları, Ankara, 2. Baskı, Kasım 2006.

- Ata Nirun, a.g.e, s. 208.

- Bayraktar Bayrakl1, "Kıyamet ne Zaman Kopacak” Haber Türk, 21 Aralık 2012.

- Carl Schmitt, "Political Theology(1922)”, Çev. George Schwab, MIT Press, Camb. MA, 1985.

- Carl Scmitt, "The Concept of the Political" (1932), Çev: George Schwab, University of Chicago Press, Chicago, 1996.

- Daniel Yergin, "Shattered Peace: The Origins of the Cold War", Penguin, Harmondsworth, 1980.

- David Isenberg, "Welcome to the Postmodern Warfare Era", Intellectual Capital.com, Cilt. 5, Sayı. 40, 30 Ekim 2000.

- Derek Gregory, “The Colonial Present", Blackwell, Oxford, 2004.

- Dücane Cündioğlu, "Sinema ve Felsefe", Kapı Yayınları, İstanbul, 2012.

- Edward Mead Earle, "American Security: Its Changing Conditions" Annals of the American Academy of Political and Socience, No. 218, 1941.

- F. D. Roosevelt, "Press Conference", 28 Aralık 1943, The Public Papers and Addresses of Franklin D. Roosevelt içinde, 1943, Harper and Brothers, New York, 1950.

- François Debrix, "Tabloid Terror: War, Culture and Geopolitics”, Routledge, Londra, 2008.

- Franklin D. Roosevelt, "Annual Massage to the Congress", 4 Ocak 1939, Public Papers içinde, Vol. Macmillan, Londra, 1941.

- Franklin D. Roosevelt, "Eleventh State of the Union Address" 11 Ocak 1944, in the Public Papers and Addresses of Franklin D. Roosevelt 1944-1945, Harper and Brothers, New York 1950.

- Franz Schurman, “The Logic of World Power”, Pantheon Books, New York, 1974.

- Grace Halsell, “Tanrı’yı Kıyamete Zorlamak”, Türkçesi: Mustafa Acar-Hüsnü Özmen, 2. Baskı, Kim Yayınları, Ankara, 2003.

- Haber Türk, 14 Kasım 2012.

- Hasan Bülent Kahraman, Pazar Akşam, 20 Haziran 2010.

- Hürriyet, 16 Aralık 2012.

- James Rickards, "Kur Savaşları-Bir Sonraki Küresel Krizin Oluşumu”, Türkçesi: Neşenur Domaniç ve Nusret Avhan, Scala Yayıncılık, İstanbul, 2013.

- Jeremy Black, "Maps and Politics”, Reaktion Books, Londra, 1997.

- Joseph Nye, "Seven Tests: Between Concert and Unilateralism", The National Interest, Sayı. 66, Kış 2001/2.

- Klaus Ulrich, Almanya'nın Sesi radyosu-Turquie Diplomatique 15 Ekim-15 Kasım 2012, Sayı. 45.

- Leyla Coşan, "Kıyamet Alameti Türkler”, Yeditepe yayınları, İstanbul, 2012.

- M. I. Abromowitz, Nationalinterest, 20 Eylül 2012.

- Mark Neocleous, “Güvenlik Şiddet ve Savaş”, Türkçesi: Gül Çorbacıoğlu-Ersin Emkel, Dipnot Yayınları, Ankara, 2012.

- Mark Neocleous, "İmagining the State", -Milton Keynes: Open University Press, 2003.

- Mehmet Şevket Eygi, “İyiler Kötüler”, Milli Gazete, 27 Nisan 2006.

- Mehmet Şevket Eygi, Milli Gazete, 27 Nisan 2006.

- Melvyn P. Leffler, "A Preponderance of Power: National Security, the Truman Administration and the Cold War", Stanford University Press, CA, 1992.

- $\quad$ Mine G. Kirıkanat, Cumhuriyet, 1 Temmuz 2012.

- Naomi Klein, "Şok Doktrini-Felaket Kapitalizmin Yükseliş̧”, Türkçesi: Selim Özgül, Agora Kitaplığı, İstanbul, 2010. 
- $\quad$ NSC-68, 14 Nisan 1950, Thomas H. Etzold and John Lewis Gaddis (Der.), Containment: Documents on American policy and Strategy içinde 1945-1950, Columbia University Press, New York, 1978.

- Oded Yinon, Kivunim, Şubat 1982, Sayı. 14.

- Paul Virilio, "Negative Horizon (1984)”, Çev. Michael Degener, Continuum, Londra, 2005.

- Pierre Bourdieu, "Outline of a Theory of Practice", Çev. Richard Nice, Cambridge University Press, Cambridge, 1977.

- Ramazan Kurtoğlu, “Evanjelizm”, 3. Baskı, Sinemis Yayınları, Ankara, 2012.

- Ramazan Kurtoğlu, “Küresel Ekonomik Kriz ve Yeni Dünya Düzeni”, Sinemis Yayınları, Ankara, 2012.

- Robert A. Pollard, "Economic Security and the Origins of the Cold War 1945-1950", Columbia University Press, New York, 1985.

- $\quad$ Robert D. Kaplan, “On the Coming Ararchy on Our Planet”, The Atlantic Monthly, Şubat 1994.

- Sait Yılmaz, Akıllı Güç, Kum Saati Yayınları, İstanbul, 2002.

- Samuel Huntington, “The Lonely Superpower”, Foreign Affairs, Cilt. 78, Say1. 2, Mart-Nisan 1999.

- Samuel P. Huntington, "Medeniyetler Çatışması ve Dünya Düzeninin Yeniden Kurulması”, Türkçesi: Mehmet Turan-Cem Soydemir, Okuyan Us Yayın, İstanbul, 2002.

- Saule Baycaunova, "Kazakistan Petrol ve Gazının Türk ve Rus Dış Politikalarındaki Yeri ve Önemi”, Avrasya Dosyası, Yaz 2000, Cilt: 6, Say1: 2.

- Sedat Ergin, ABD İstihbaratının Gözünde 2030 Türkiyesi”, Hürriyet, 21.12.2012.

- Selin Çağlayan, “İran-Mehdi’yi Beklerken”, Cinius Yayınları, İstanbul, 2012.

- Serdar Turgut, "Coğrafya”, Haber Türk, 27 Kasım 2012.

- Serdar Turgut, "Herkesi Şaşırtan İhtiyar”, Haber Türk, 25 Kasım 2012.

- Serdar Turgut, “İsrail-Türkiye Savaşı ve Armagedon”, Haber Türk, 22 Kasım 2012.

- Serdar Turgut, Haber Türk, 23 Temmuz 2012.

- Serdar Turgut, Haber Türk, Derin Dünya Türkiye’yle Uğraşıyor, 10 Ocak 2013.

- Simon Dalby, "Environmental Security”, University of Minnesota Press, Minneapolis, 2002.

- Terence Corcoran, "Free Markets Lose Their Last Lion”, National Post Toronto, 17 Kasım 2006.

- The Economist, "Lets All go to the Yard Sale: Iraq's Economic Liberalisation”, 27 September, 2003.

- Ümit Özdağ, -Sait Yılmaz, “Akıllı Güç”, içinde, Kum Saati Yayınları, İstanbul, 2012.

- Vahiy 13: 3,4,8.

- Vahiy 13:16-17.

- Vahiy 13:7; Daniel 7:23.

- Zafer Toprak, “Türkiye'de Milli İktisat 1908-1918” Doğan Kitap, İstanbul, 2012.

- Zygmunt Bauman, “Modernity and Ambivalence”, Polity Press, Cambridge, 1991. 